\title{
Toxicological and Biological Effects of Abamectin, Malathion and Three Plant Oils Singly and in Combination on Cowpea Weevil, Callosobruchus maculatus (F.).
}

Manal A. A. Abd ELrazik

Pesticides Department, Fac. Agriculture Menoufia Univ., Shebin Elkom, Egypt

E mail: new1folder@yahoo.com

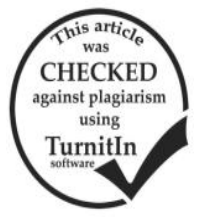

The toxicological and biological effects of abamectin, malathion and three plant oils (olive oil, peanut oil and linseed oil) singly and in three mixture ratios $(5: 95,10: 90$ and 15:85) of the oils and insecticides, were evaluated on cowpea beetle, Callosobruchus maculatus (F.) infested cowpea seeds. Abamectin showed synergistic activity when combined with olive oil and peanut oil at the three mixing ratios recording co- toxicity coefficient values, (128.90, 276.08 and 371.55) and (110.85, 135.96 and 205.72), respectively. Malathion exhibited high synergistic activity with linseed oil at the three mixing ratios recording co toxicity coefficient values $174.56,307.42$ and 472.73 , respectively. Also, malathion and peanut oil showed synergistic activity at 90:10 and 85:15 mixing ratios recording co toxicity coefficient value 114.95 and 163.80, respectively. The activity of abamectin and malathion singly or in mixtures with the three oils were significantly increased, particularly at the higher concentrations. Malathion combinations with olive oil and linseed oil were more effective than those with abamectin in reducing number of laid eggs. Abamectin in combination with olive or linseed oils was more effective than those of malathion in suppressing egg hatchability. It was reported that abamectin mixtures with the three tested oils were more effective than those with malathion in decreasing the number of emerged adults. A complete protection of treated seeds was achieved with the mixture of olive oil: abamectin at 10: 90 mixing ratio, peanut oil: abamectin at 5:95 \& 10:90 mixing ratio, at the concentrations of 500 and 1000 ppm, respectively. It could be concluded that the use of plant oils combined with pesticides increase the mortality of the cowpea beetle stages, as well as decrease the use of the chemicals to save the environment from pesticide pollution.

Keywords: Stored seeds, joint action, plant oils, mixtures

\section{INTRODUCTION}

Cowpea seed weevil Callosobruchus maculatus (F.) considered one of the most important insect pests of legumes in field and stores. The cowpea weevil multiplies very rapid in storage, giving rise to a novel generation each month (Ouedrago et al., 1996). Cowpea weevil can completely injured all stored seeds, causing weight losses up to $60 \%$ (Kieta et al., 2000), therefore, it is essential to decrease such losses by controlling pests on stored grains (Tapondjou et al., 2002).

To avoid some losses throughout storage the use of pesticides is considered one of the mandatory means. On the other hand, the choice of pesticides for storage of pest control is very limited because of the strict requirements for the harmless use of synthetic insecticides on or near foods. Severe problems have caused due to the continuous use of chemical pesticides such as insecticides resistance (Pacheco et al., 1990, Sartori et al., 1990). Tembo \& Murfitt (1995) treated wheat grains with vegetable oil combined with pirimiphos methyl at half recommended dose and found that it was very effective against Sitophilus granaries.

The usage of vegetable plant oils has revealed a strong activity against $C$. maculatus which can be beneficial as another source of botanical pesticide (Abdelrazik et al., 2013), and the application of insecticide/oil mixture may minimize insecticides usage and reduced amount of used insecticides.

The use of botanical oils alone were less effective than commercial insecticides and the possibility of using botanical oils in combination with synthetic insecticide in simple mixture to be more attractive and effective (Don Pedro, 1989 a \&b). Dilute malathion was more effective than malathion which applied topically concentrated on the desert locust (Ahmed \& Gradiner, 1967).

From the previous results, this research was conducted to study the effect of three plant oils and two pesticides singly and in combination on the biological aspects of the cowpea beetle, $C$. maculatus infesting treated cowpea seeds, under laboratory conditions.

\section{MATERIALS AND METHODS}

\section{Cowpea weevil rearing and cowpea seeds:}

The culture of the cowpea beetle, Callosobruchus maculatus (F.) was obtained from the biological laboratory of the Economic Entomology Department, Faculty of Agriculture, and Menoufia University, Egypt where it was reared on cowpea seeds under laboratory conditions of $25 \pm 2 \mathrm{C}^{\circ}$ and $65 \pm 5 \% \mathrm{RH}$.

The cowpea seeds, Vigna unguiculata variety Dokki 331 were used for insect culture and experiments, which were previously sterilized by freezing at $-4 \mathrm{C}^{\circ}$ for one week to kill off any prior insect infestation, then left to dry in the room temperature and stored in sealed polyethylene bags in the refrigerator at $5{ }^{\circ} \mathrm{C}$ until required for experiments. (Abo Elghar et al., 2003).

Tested insecticides and plant oils:

The naturally derived pesticide abamectin (Vertemic 18\% EC) and the organo phosphorous insecticide malathion (malathion $57 \% \mathrm{EC}$ )), in addition to three locally produced plant oils: peanut, Arachis hypogaea, olive, Olea europaea, and linseed, Linum usitatissimum oils, were tested against cowpea weevil singly and in combination with the evaluated insecticides. The oils were obtained from a chemical company as refined oils.

\section{Toxicological studies:}

Joint action of abamectin, malathion and three plant oils on $C$. maculatus:

To test the mortality of the adults of C. maculatus by abamectin, malathion and three plant oils when used as contact method, $60 \mathrm{~g}$ of cowpea seeds were sprayed with $10 \mathrm{ml}$ of each concentration of tested compounds and plant oils alone and their mixture, five concentrations 
were used at 95:5, 90:10 and 85:5 (insecticides:oil) and left to dry. The sixty grams of treated seeds were divided into three replicates and transferred to $500 \mathrm{ml}$ glass jars. Twenty adults ( $24 \mathrm{~h}$ old) were used for each replicate. A similar sample (60 g of cowpea seeds) were sprayed with water and left to dry and used as control. Glass jars were covered with fine mesh cloth.

Mortality was recorded after $24 \mathrm{~h}$ and corrected according to Abbott's formula (Abbott, 1925). The $\mathrm{LC}_{50}$ values were computed by log probit analysis (Finney 1971). The co toxicity coefficient factor was computed according to Sun and Johanson (1960).

\section{Biological effects :}

To treat the cowpea seeds, $60 \mathrm{~g}$ were placed in a glass beaker $100 \mathrm{ml}$, then $10 \mathrm{ml}$ of aqueous dispersion of the tested compound (oil or insecticide or their mixtures) at concentrations of $10,50,500$ and 1000 ppm of 5:95, 10:90 and 15:85 ratios of oil: insecticide for each concentration was pipette on seed surface and mixed thoroughly by shaking for $10 \mathrm{~min}$ (Onolemhemhem, 2001). The treated seeds were spread above plates covered with polyethylene sheet and left to dry. A similar sample $(60 \mathrm{~g})$ of untreated seeds were sprayed with water and left to dry to be used as control .Twenty grams of each treated seeds were transferred to Petri dishes $(10 \mathrm{~cm}$ diameter $)$, and replicated three times.

Ten sexed pairs of $C$. maculatus ( $24 \mathrm{~h}$ old) were put in each Petri dish which contains the treated seeds and covered with glass cover, and allowed to lay eggs for 3 days .On the fourth day, adults were removed, and the number of laid eggs on treated seeds was counted. At the ninth day, the number of non-hatched eggs was recorded and hatchability percent was calculated.

Biological aspects

The hatchability percentage was calculated using the following formula:

$$
\text { Hatchability\% }=\frac{\text { Mean no. of egg hatched }}{\text { Mean no. of egg laid }} \times 100
$$

The Petri dishes of treated cowpea seeds infested with $C$. maculatus were kept in the laboratory under $25 \pm 2 \mathrm{C}^{\circ}$ and $65 \pm 5 \% \mathrm{RH}$ until the emergency of all adults. The $C$. maculatus adults were daily counted from the beginning of the first emergency of adults along 2 weeks (Onolemhemhem, 2001). The percent of emerged adults waw calculated by the following equation:

Emergence\% $=$ Mean no. of emerged adult $\times 100$ Mean no. of egg laid

After emergency of adults, seeds were weighed after excluding the faces and dust. The weight loss of seeds was calculated using the following equation (Khare and Johari, 1984):

\section{Weight loss\% $\%$ Initial dry weight - final dryweight $\times 100$ initial dry weight}

The reduction percentage of mean number of laid egg and emerged adults were calculated by the following equation:

Reduction $\%=$ Mean no. in control-mean no. in treatment $\times 100$ Mean no. in control

\section{Statistical analysis:}

Decrease percentages in laid egg numbers, hatchability percentages, number of emerged adults, and weight loss $\%$ of cowpea seeds were calculated.

The data were statistically analyzed using (ANOVA) test at $5 \%$ probability, where the measurements were divided using Duncan's Multiple Range Test (DMRT) through CoStat software program (Version 6.400).

\section{RESULTS AND DISCUSSION}

Joint action of tested insecticides and plant oil mixtures against adult stage of cowpea weevil:

The $\mathrm{LC}_{50}$ and co-toxicity coefficient factor of abamectin, malathion and three plant oil mixtures at 95:5, 90:10 and 85:15 mixing ratios (insecticides:oil) against adult stage of Callosobruchus maculatus were calculated and presented in Table (1). A synergistic activity was detected in abamectin + olive oil and abamectin+ peanut oil at all mixing ratios recording $\mathrm{LC}_{50}$ values (470.71, 231.63 and 181.93) and (547.09, 469.90 and 328.12), respectively, and recording cotoxicity coefficient values $(128.90,276.08$ and 371.55$)$ and (110.8, 135.96 and 205.72), respectively. Furthermore, abamectin and linseed oil mixtures showed antagonistic effect except at 85:5 mixing ratio which exhibited synergistic activity recording cotoxicity coefficient value 119.95 .

Table 1. Toxicity and co-toxicity coefficient of mixtures of abamectin, malathion and three plant oils on adult stage of Cowpea weevil (C. maculatus).

\begin{tabular}{|c|c|c|c|c|c|}
\hline Mixtures & Mixing ratios & LC50 (ppm) & Slope & Confidence limits & Co toxicity coefficient \\
\hline \multirow{3}{*}{ Abamectin.+ olive oil } & $95: 5$ & 470.71 & $1.015 \pm 0.186$ & $275.831-1041.426$ & 128.90 \\
\hline & $90: 10$ & 231.63 & $1.141 \pm 0.183$ & $146.349-394.876$ & 276.08 \\
\hline & $85: 15$ & 181.93 & $1.169 \pm 0.181$ & $115.608-297.536$ & 371.55 \\
\hline \multirow{3}{*}{ Abamectin +peanut oil } & $95: 5$ & 547.09 & $1.061 \pm 0.159$ & $346.428-951.894$ & 110.85 \\
\hline & $90: 10$ & 469.90 & $1.138 \pm 0.164$ & $305.577-769.107$ & 135.96 \\
\hline & $85: 15$ & 328.12 & $1.027 \pm 0.149$ & $205.749-543.978$ & 205.72 \\
\hline \multirow{3}{*}{ Abamectin + linseed oil } & $95: 5$ & 951.36 & $1.134 \pm 0.217$ & $591.518-1809.321$ & 63.70 \\
\hline & $90: 10$ & 858.44 & $1.137 \pm 0.212$ & $535.665-1576.656$ & 74.31 \\
\hline & $85: 15$ & 561.31 & $0.833 \pm 0.159$ & $305.305-1172.866$ & 119.95 \\
\hline \multirow{3}{*}{ malathion +olive oil } & $95: 5$ & 1808.3 & $0.954 \pm 0.175$ & $1083.03-3756.425$ & 25.86 \\
\hline & $90: 10$ & 789.22 & $1.018 \pm 0.161$ & $487.797-1307.279$ & 62.24 \\
\hline & $85: 15$ & 440.78 & $0.949 \pm 0.143$ & $255.653-728.461$ & 118.25 \\
\hline \multirow{3}{*}{ malathion + peanut oil } & $95: 5$ & 832.66 & $1.094 \pm .214$ & $471.818-2210.184$ & 56.12 \\
\hline & $90: 10$ & 428.49 & $0.995 \pm 0.182$ & $250.84-934.421$ & 114.95 \\
\hline & $85: 15$ & 317.87 & $0.967 \pm 0.175$ & $186.960-648.795$ & 163.80 \\
\hline \multirow{3}{*}{ malathion + linseed oil } & $95: 5$ & 267.57 & $0.995 \pm 0.182$ & $250.84-934.421$ & 174.56 \\
\hline & $90: 10$ & 160.03 & $0.854 \pm 0.165$ & $137.413-523.531$ & 307.42 \\
\hline & $85: 15$ & 109.92 & $0.828 \pm 0.163$ & $71.890-273.162$ & 472.73 \\
\hline
\end{tabular}


As for mixtures of malathion and plant oils Table (1) results clearly show that the mixtures of malathion and linseed oil recorded high synergistic effect at all mixing ratios where the $\mathrm{LC}_{50}$ values were 267.57, 160.03 and 109.92 with co- toxicity coefficient values 174.56, 307.42 and 472.73. On the other side, the mixture of malathion and olive oil recorded antagonistic effect nearly at all mixing ratios except 85:5 mixing ratio which exhibited synergistic activity. The combinations of malathion and peanut oil show synergistic activity at $90: 10$ and $85: 5$ mixing ratios recording co- toxicity coefficient values 114.95 and 163.80 , respectively, while 95:5 mixing ratio showed antagonistic action and co-toxicity coefficient 56.12.

The obtained results are confirmed with those of Tembo and Murfitt (1995) who found significant mortality by groundnut, rape seeds and peanut oils, alone and in combination with pirimiphos-methyl at rates $1 / 2,1 / 3$ or $1 / 4$ from recommended rate against Sitophilus granaries compared to check. Also, Sridevi and Dhingra (1996, 2000) evaluated the efficacy of deltamethrim and in mixture with linseed, neem and citronella oils at four ratios $(1: 1,1: 2,1: 4,1: 8)$ against susceptible and resistant strains of $T$. castaneum adults by direct spray and film residue methods and found that all vegetable oils had additive action. The usage of vegetable plant oils has revealed a strong activity against Callosobruchus maculatus which can be beneficial as another source of botanical pesticide (Abdelrazik et al., 2013), and the application of insecticide/oil mixture may minimize insecticides usage and reduced amount of used insecticides.

Biological and toxic effects of tested insecticides and plant oils alone and in combination against cowpea weevil (C. maculatus):

Data in Table (2) indicated that the concentrations $10,50,100,500,1000 \mathrm{ppm}$ of the three oils were significantly inhibited the females of $C$. maculatus from laying eggs on treated cowpea seeds compared to control treatment and $10 \mathrm{ppm}$ concentrations of the tested oils (LSD 5\% = 19.8). The highest reduction percentages in the numbers of laid eggs were $(76.1,83.4$, and $91.2 \%)$ at the treatments of olive oil, peanut oil and linseed oil, respectively under $1000 \mathrm{ppm}$ concentration in comparison with untreated check.

Regarding to the hatching percentages of the eggs, there were no significant differences between evaluated oils and check except 1000 ppm of olive oil and linseed oil, 500 and 1000 ppm for peanut oil and check where the difference was not significant (LSD 5\% $=7.1$ ) where the highest hatching percentages were recorded at 10 and $50 \mathrm{ppm}$ of linseed oil and check resulting 98.5, 96 and $99 \%$, respectively.

Table 2. Effect of olive, peanut and linseed oils on eggs, hatchability, emerged adults and food consumption of $C$. maculatus infested treated cowpea seeds

\begin{tabular}{|c|c|c|c|c|c|c|}
\hline $\begin{array}{l}\text { Concentration } \\
(\mathrm{ppm})\end{array}$ & $\begin{array}{l}\text { Mean no. laid } \\
\text { eggs/female }\end{array}$ & $\begin{array}{c}\text { Reduction } \\
\%\end{array}$ & $\begin{array}{c}\text { Hatchability } \\
(\%)\end{array}$ & $\begin{array}{c}\text { Mean no of } \\
\text { emerged adults }\end{array}$ & $\begin{array}{c}\text { Reduction } \\
\%\end{array}$ & $\begin{array}{c}\text { weight } \\
\text { loss of seeds }(\%)\end{array}$ \\
\hline \multicolumn{7}{|l|}{ Olive oil } \\
\hline 10 & $357 \mathrm{~b}$ & 7.03 & $92.9 \mathrm{abc}$ & $112 \mathrm{~d}$ & 50.3 & $55.7 \mathrm{a}$ \\
\hline 50 & $252 \mathrm{c}$ & 34.4 & 90.7 abc & 90 ef & 60.0 & $53.8 \mathrm{a}$ \\
\hline 100 & $246 \mathrm{c}$ & 35.5 & $90.5 \mathrm{abc}$ & $72 \mathrm{fgh}$ & 68.1 & $53.2 \mathrm{a}$ \\
\hline 500 & $130 \mathrm{~g}$ & 66.2 & $88.4 \mathrm{abc}$ & $61 \mathrm{ghi}$ & 72.9 & $52.8 \mathrm{a}$ \\
\hline 1000 & $91.7 \mathrm{hi}$ & 76.1 & $86 \mathrm{bc}$ & $52 \mathrm{hi}$ & 76.9 & $30.5 \mathrm{~cd}$ \\
\hline \multicolumn{7}{|l|}{ Peanut oil } \\
\hline$\overline{10}$ & $345.3 \mathrm{~b}$ & 10.1 & $93.3 \mathrm{abc}$ & $143 \mathrm{c}$ & 36.5 & $43.1 \mathrm{~b}$ \\
\hline 50 & $226 \mathrm{~d}$ & 41.2 & $93.0 \mathrm{abc}$ & $97 \mathrm{de}$ & 56.9 & $37.2 \mathrm{bc}$ \\
\hline 100 & $180 \mathrm{e}$ & 53.1 & $92.1 \mathrm{abc}$ & $81 \mathrm{efg}$ & 64.1 & 29.5 cde \\
\hline 500 & $99 \mathrm{~h}$ & 74.2 & $84.7 \mathrm{bc}$ & 69 ghi & 69.4 & 21.6 ef \\
\hline 1000 & $63.7 \mathrm{j}$ & 83.4 & $83 \mathrm{c}$ & $48 \mathrm{i}$ & 78.7 & $13.9 \mathrm{f}$ \\
\hline \multicolumn{7}{|l|}{ Linseed oil } \\
\hline$\overline{10}$ & $353.3 \mathrm{~b}$ & 7.9 & $98.5 \mathrm{a}$ & $161 \mathrm{~b}$ & 28.6 & 22.6 def \\
\hline 50 & $199.3 \mathrm{c}$ & 48.1 & $96 \mathrm{ab}$ & $101 \mathrm{de}$ & 55.2 & $17.8 \mathrm{f}$ \\
\hline 100 & $154.7 \mathrm{f}$ & 59.7 & $91 \mathrm{abc}$ & $93 \mathrm{de}$ & 58.7 & $15.7 \mathrm{f}$ \\
\hline 500 & $75 \mathrm{ij}$ & 80.5 & $88 \mathrm{abc}$ & 62 ghi & 72.5 & $13.9 \mathrm{f}$ \\
\hline 1000 & $33.7 \mathrm{k}$ & 91.2 & $84 \mathrm{bc}$ & $22 \mathrm{j}$ & 90.2 & $12.7 \mathrm{f}$ \\
\hline Untreated & $384 \mathrm{a}$ & - & $99.0 \mathrm{a}$ & $225.3 \mathrm{a}$ & - & $56.0 \mathrm{a}$ \\
\hline LSD (0.05) & 19.8 & & 7.1 & 15.3 & & 6.5 \\
\hline
\end{tabular}

Means followed by the same letters in a column insignificantly differences at $0.05 \%$ level.

Statistical analysis of the data on the mean number of emerged adults (Table 2) revealed that all tested oils were significantly differences compared with untreated (LSD $5 \%=15.3$ ), where the lowest mean number of emerged adults was recorded with linseed oil treatment at 1000 ppm giving 22 adults compared with 225.3 adults at control. The highest reduction percentage in the numbers of emerged adults was recorded at the treatment of linseed oil 1000 ppm recording $90.2 \%$.

Furthermore, statistical analysis of the data Table (2) indicate that there were significant differences in the weight loss percentages between control and all other treatments except that of olive oil $(10,50,100,500 \mathrm{ppm})$
(LSD $5 \%=6.5$ ). The least weight loss percentages of seeds were recorded at the treatments of linseed oil ranging between (12. $7-22.60 \%$ ), moreover it was only $13.9 \%$ at the treatment of peanut oil at $1000 \mathrm{ppm}$.

The oil plants reduce oviposition rate and suppress adult emergence of bruchids and reduce seed damage rate which confirmed with those obtained by (Tapondjou et al., 2002, Swella and Mushobozy, 2007). The survival of immature stages of C. chinensis was completely inhibited by the neem and sesame oils as well as adult emergence and appeared to be most promising as seed protectant against the insect. In addition Ahmed et al. (1999) found that, the survival of immature stages of $\mathrm{C}$. chinensis was 
completely inhibited by neem and sesame oils as well as adult emergence. Also, (Adebowale and Adedire, 2006) reported that oil coating seeds prevent $\mathrm{C}$. maculatus eggs to firmly attach to the seed coat and inhibit larval penetration into seed. Finally, Mulatu and Gebremedhim (2000) showed that Adzuki bean beetle, Callosobruchus chinensis was completely preventing from egg laying on stored faba bean seeds, and no bruchids emerged from the laid few eggs by oils of Azadirachta indica, Milletiaie ferruginea and Chrysanthemum cineraraefolium.

Effect of the tested insecticides against cowpea weevil:

Data presented in Table (3) indicated that all the concentrations of the two insecticide (abamectin and malathion) were significantly inhibited the females of $\mathrm{C}$. maculatus from laying eggs on cowpea seeds in comparison with untreated (LSD 5\% $=16.6$ ), while there were no significant differences between the highest concentrations of malathion (100, 500, $1000 \mathrm{ppm})$.

The highest reduction percentages in the numbers of laid eggs were $(98.3 \%)$ at the treatments of malathion under $1000 \mathrm{ppm}$ concentration in comparison with untreated check.

Table 3. Effect of abamectin and malathion concentrations on eggs, hatchability, emerged adults, and food consumption of C.maculatus infest treated cowpea seeds

\begin{tabular}{|c|c|c|c|c|c|c|}
\hline $\begin{array}{l}\text { Concentration } \\
(\mathrm{ppm})\end{array}$ & $\begin{array}{c}\text { Mean } \\
\text { no. laid } \\
\text { eggs/ } \\
\text { female } \\
\end{array}$ & $\begin{array}{c}\text { Reduction } \\
\%\end{array}$ & $\begin{array}{c}\text { Hatchability } \\
(\%)\end{array}$ & $\begin{array}{c}\text { Mean no } \\
\text { of } \\
\text { emerged } \\
\text { adults }\end{array}$ & $\begin{array}{c}\text { Reduction } \\
\%\end{array}$ & $\begin{array}{c}\text { Weight } \\
\text { loss of } \\
\text { seeds } \\
\% \\
\end{array}$ \\
\hline \multicolumn{7}{|l|}{ Abamectin } \\
\hline$\overline{10}$ & $150 \mathrm{c}$ & 60.9 & $94.3 \mathrm{ab}$ & $49 \mathrm{bc}$ & 78.3 & $21.2 \mathrm{~b}$ \\
\hline 50 & $130 \mathrm{~d}$ & 66.2 & $88 \mathrm{bcd}$ & 36 cde & 84.0 & $17 \mathrm{bc}$ \\
\hline 100 & $115.6 \mathrm{de}$ & 60.9 & $85 \mathrm{~cd}$ & $24 \mathrm{ef}$ & 89.3 & $14.7 \mathrm{~cd}$ \\
\hline 500 & $106 \mathrm{e}$ & 72.4 & $78 \mathrm{e}$ & 19 ef & 91.6 & $11.7 \mathrm{~cd}$ \\
\hline 1000 & $81.5 \mathrm{f}$ & 78.8 & $63 \mathrm{f}$ & $7 \mathrm{f}$ & 96.9 & $10 \mathrm{~cd}$ \\
\hline \multicolumn{7}{|l|}{ Malathion } \\
\hline 10 & $172 \mathrm{~b}$ & 55.2 & $96.76 \mathrm{a}$ & $54 \mathrm{~b}$ & 76.0 & $14.7 \mathrm{~cd}$ \\
\hline 50 & $82.7 \mathrm{f}$ & 78.7 & $94 \mathrm{ab}$ & $42 \mathrm{bcd}$ & 81.4 & $12.3 \mathrm{~cd}$ \\
\hline 100 & $26.7 \mathrm{~g}$ & 93.1 & $92.3 \mathrm{abc}$ & $31 \mathrm{de}$ & 86.2 & $9 \mathrm{~d}$ \\
\hline 500 & $14.7 \mathrm{~g}$ & 96.2 & $86.1 \mathrm{~cd}$ & 22 ef & 90.2 & $4 \mathrm{e}$ \\
\hline 1000 & $6.7 \mathrm{~g}$ & 98.3 & $81 \mathrm{de}$ & $9 \mathrm{f}$ & 96.0 & $2 \mathrm{e}$ \\
\hline Untreated & $384 \mathrm{a}$ & - & $99.0 \mathrm{a}$ & $225.3 \mathrm{a}$ & - & $56.0 \mathrm{a}$ \\
\hline $\operatorname{LSD}(0.05)$ & 16.6 & & 5.5 & 12 & & 4.8 \\
\hline
\end{tabular}

Means followed by the same letters in a column insignificantly differences at $0.05 \%$ level.

Regarding to the hatching percentages of the eggs, there were significant differences between all concentrations of abamectin and untreated check (LSD $5 \%=5.5$ ) except at $10 \mathrm{ppm}$. The least hatchability percentages were recorded at malathion treatment of 1000 ppm resulting $63 \%$ comparing with $99 \%$ at check treatment.

Statistical analysis of the data on the mean numbers of emerged adults (Table 3 ) revealed that there were significant differences between all tested concentrations of the two insecticides and untreated (LSD $5 \%=12$ ), where the lowest mean number of emerged adults was recorded with abamectin and malathion treatments at 1000 ppm giving 7 and 9 adults, respectively without significant differences compared with 225.3 adults at untreated control. The highest reduction percentage in the numbers of emerged adults was recorded at the treatment of abamectin and malathion treatments at $1000 \mathrm{ppm}$ recording 96.9 and $96 \%$, respectively.
The statistical analysis of the data in Table (3) indicate that there were significant differences in the weight loss percentages between control treatment and all insecticide concentrations (LSD 5\% = 4.8). The least weight loss percentages of seeds were recorded at the treatments of malathion ranging between (2-14.7\%) comparing with $56 \%$ at control, while it was ranged between $10-21.2 \%$ at abamectin treatments. These results are in harmony with those of Mohamed et al. (2009) who reported that avermectin compound in concentrations of $0.5,2.5 \mathrm{ppm}$ and untreated seeds averaged hatchability of $C$. maculates by $69.73,44.81$ $\%$ and $90.05 \%$, respectively.

\section{Combined effect of insecticides and tested oils on $C$. maculatus:}

The results in Table (4) show the effect of the mixture ratios of the tested insecticides and plant oils on the mean number of laid eggs by cowpea weevil female. Statistical analysis of the data Table (4) indicated that the numbers of laid eggs were significantly differences compared with control and all other treatments.

Table 4. Effect of abamectin and malathion at three mixture ratios with olive, peanut and linseed oils on deposit eggs / female of C. maculatus

\begin{tabular}{|c|c|c|c|c|c|c|}
\hline \multirow{2}{*}{$\begin{array}{l}\text { Conc. } \\
\text { (ppm) }\end{array}$} & \multicolumn{6}{|c|}{ Mean no. of laid eggs/female (Reduction \%) } \\
\hline & \multirow{3}{*}{$\begin{array}{c}\begin{array}{c}\text { Olive } \\
\text { Abamectin }\end{array} \\
\text { icide 5:95 } \\
42 \mathrm{~b}\end{array}$} & \multirow{2}{*}{$\begin{array}{l}\text { e oil } \\
\text { Malathion }\end{array}$} & \multicolumn{2}{|c|}{$\begin{array}{c}\text { Peanut oil } \\
\text { abamectin Malathi }\end{array}$} & \multicolumn{2}{|c|}{$\begin{array}{c}\text { Linseed oil } \\
\text { abamectin malathion }\end{array}$} \\
\hline \multicolumn{5}{|c|}{ oil : insecticide 5:95 } & & \\
\hline 10 & & $\begin{array}{l}160 \mathrm{~b} \\
(58.3)\end{array}$ & $\begin{array}{l}110 \mathrm{~b} \\
(71.3)\end{array}$ & $\begin{array}{l}110 \mathrm{~b} \\
(71.4)\end{array}$ & $\begin{array}{l}300 \mathrm{~b} \\
(21.9)\end{array}$ & $\begin{array}{l}114 \mathrm{~b} \\
(70.3)\end{array}$ \\
\hline 50 & $\begin{array}{l}20 \mathrm{c} \\
(94.8)\end{array}$ & $\begin{array}{c}82 \mathrm{e} \\
(78.7)\end{array}$ & $\begin{array}{l}57.3 \mathrm{~d} \\
(85.1)\end{array}$ & $\begin{array}{c}65 \mathrm{~d} \\
(83.1)\end{array}$ & & $\begin{array}{l}62.7 \mathrm{c} \\
(83.7)\end{array}$ \\
\hline 100 & $\begin{array}{l}11.3 \mathrm{c} \\
(97.1)\end{array}$ & $\begin{array}{l}31 \mathrm{~g} \\
(91.9)\end{array}$ & $\begin{array}{l}27.3 \mathrm{ef} \\
(92.9)\end{array}$ & $\begin{array}{c}59 \mathrm{~d} \\
(84.6)\end{array}$ & & $\begin{array}{l}41.3 \mathrm{~d} \\
(89.2)\end{array}$ \\
\hline 500 & $\begin{array}{l}8.7 \mathrm{c} \\
(97.7)\end{array}$ & $\begin{array}{l}19 \mathrm{ghi} \\
(95.1)\end{array}$ & $\begin{array}{l}16 \text { efg } \\
(95.8)\end{array}$ & $\begin{array}{l}38 \text { ef } \\
(90.0)\end{array}$ & $\begin{array}{c}47.3 \mathrm{de} \\
(87.7)\end{array}$ & $\begin{array}{l}32.3 \mathrm{~d} \\
(91.6)\end{array}$ \\
\hline 000 & $\begin{array}{l}5.7 \mathrm{c} \\
(98.5)\end{array}$ & $\begin{array}{r}12.3 \\
(96 \\
\end{array}$ & $\begin{array}{c}6 \mathrm{~g} \\
(98.4)\end{array}$ & & $12 \mathrm{e}$ & $\begin{array}{l}10 \mathrm{e} \\
(97.4)\end{array}$ \\
\hline \multicolumn{7}{|c|}{ oil: insecticide 10:90 } \\
\hline 10 & $\begin{array}{c}44 \mathrm{~b} \\
(88.5)\end{array}$ & $\begin{array}{l}130 \mathrm{c} \\
(66.2)\end{array}$ & $\begin{array}{l}105 \mathrm{bc} \\
(72.7)\end{array}$ & & & $\begin{array}{c}6 \mathrm{e} \\
(98.4)\end{array}$ \\
\hline 0 & $\begin{array}{l}35 \mathrm{~b} \\
(90.9)\end{array}$ & & $\begin{array}{l}32 \mathrm{e} \\
(91.7)\end{array}$ & & & $\begin{array}{c}3 \mathrm{e} \\
(99.2)\end{array}$ \\
\hline 100 & $\begin{array}{l}15 \mathrm{c} \\
(90.1)\end{array}$ & & $\begin{array}{c}20.7 \mathrm{efg} \\
(94.6)\end{array}$ & $\begin{array}{l}20 \\
(94\end{array}$ & & $\begin{array}{l}2.3 \mathrm{e} \\
(99.4)\end{array}$ \\
\hline 500 & $\begin{array}{l}6.3 \mathrm{c} \\
(98.3)\end{array}$ & $\begin{array}{l}16 \mathrm{hi} \\
(95.8)\end{array}$ & $\begin{array}{l}10 \mathrm{fg} \\
(97.4)\end{array}$ & $\begin{array}{l}10 \mathrm{~h} \\
(97.4)\end{array}$ & $\begin{array}{c}42.7 \mathrm{de} \\
(88.9)\end{array}$ & $\begin{array}{l}2.3 \mathrm{e} \\
(99.4)\end{array}$ \\
\hline 1000 & $\begin{array}{r}5.3 \mathrm{c} \\
(98.6)\end{array}$ & $\begin{array}{r}8 \mathrm{i} \\
(97 .\end{array}$ & $4 \mathrm{~g}$ & $\begin{array}{c}7 \mathrm{~h} \\
(98.2)\end{array}$ & $11.3 \mathrm{e}$ & $\begin{array}{c}1 \mathrm{e} \\
(99.7)\end{array}$ \\
\hline \multicolumn{7}{|c|}{ oil: insecticide 15:85 } \\
\hline 10 & $\begin{array}{l}49 \mathrm{~b} \\
(87.2)\end{array}$ & $\begin{array}{l}99 \mathrm{~d} \\
(74.2)\end{array}$ & $\begin{array}{c}95 \mathrm{c} \\
(75.3)\end{array}$ & $\begin{array}{c}88 \mathrm{c} \\
(77.1)\end{array}$ & & $\begin{array}{l}2.7 \mathrm{e} \\
(99.3)\end{array}$ \\
\hline 50 & $\begin{array}{l}34 \mathrm{~b} \\
(91.1)\end{array}$ & $38 \mathrm{~g}$ & $\begin{array}{l}13.3 \mathrm{fg} \\
(96.5)\end{array}$ & $\begin{array}{l}28 \mathrm{fg} \\
(92.7)\end{array}$ & $\begin{array}{c}54 \mathrm{~d} \\
(85.9)\end{array}$ & $\begin{array}{l}1.3 \mathrm{e} \\
(99.7)\end{array}$ \\
\hline 100 & $\begin{array}{l}20 \mathrm{c} \\
(94.7)\end{array}$ & & $\begin{array}{l}11 \mathrm{fg} \\
(97.1)\end{array}$ & & $\begin{array}{c}25.3 \mathrm{de} \\
(93.4)\end{array}$ & $\begin{array}{c}1 \mathrm{e} \\
(99.7)\end{array}$ \\
\hline 500 & $\begin{array}{l}17 \mathrm{c} \\
(95.6)\end{array}$ & $\begin{array}{l}12.3 \mathrm{hi} \\
(96.8)\end{array}$ & $6.7 \mathrm{~g}$ & $\begin{array}{c}6.7 \mathrm{~h} \\
(98.3)\end{array}$ & $\begin{array}{l}12 \mathrm{e} \\
(96.9)\end{array}$ & $\begin{array}{c}1 \mathrm{e} \\
(99.7)\end{array}$ \\
\hline 1000 & $\begin{array}{c}7 \mathrm{c} \\
(98.2)\end{array}$ & $\begin{array}{l}9.7 \mathrm{i} \\
(97.5)\end{array}$ & $\begin{array}{l}3.3 \mathrm{~g} \\
(99.1)\end{array}$ & $\begin{array}{l}4.7 \mathrm{~h} \\
(98.8)\end{array}$ & $\begin{array}{l}10.7 \mathrm{e} \\
(97.2)\end{array}$ & $\begin{array}{l}0 \mathrm{e} \\
(100)\end{array}$ \\
\hline & $384 \mathrm{a}$ & & $384 \mathrm{a}$ & & & $384 \mathrm{a}$ \\
\hline y) & 11.3 & 12 & 12.1 & 12.8 & 25.9 & 11.02 \\
\hline
\end{tabular}

Means followed by the same letters in a column insignificantly differences at $0.05 \%$ level.

It was noticed that, as mixture ratio increased the laid egg decreased in addition, the best results were recorded at the mixtures of linseed oil: malathion (10:90 and 15:85) giving only (1- 6) and (0-2.7) eggs, respectively comparing with 384 egg at control. 
All combinations were much effective at 15:85 (oil: insecticide) mixing ratio. it was found that abamectin was more effective than malathion and its component alone when it combined with olive and peanut oil, while malathion was more effective when combined with linseed oil compared with abamectin and its component alone at three mixing ratios 5:95, 10:90 and 15:85. The highest reduction percentages of the numbers of laid eggs were recorded with the mixing ratio of 15:85 of oil and insecticide at $1000 \mathrm{ppm}$ for all treatments.

It could be noticed that no egg was laid at the treatment of linseed oil and malathion of $1000 \mathrm{ppm}$ at 15: 85 ratio.

The obtained results are confirmed with Tembo and Murfitt (1995) who found that significant mortality was produced by groundnut, rape seeds and peanut oils, alone and in combination with pirimiphos-methyl at rates $1 / 2,1 / 3$ or $1 / 4$ from recommended rate against Sitophilus granaries compared to check.

As for the combined effect of abamectin and malathion at three mixture ratios with olive, peanut and linseed oils on hatchability of C. maculatus eggs (Table 5) it was reported that the combinations of abamectin with olive oil and linseed oil gave lower hatchability $\%$ than malathion and its component alone. On the other hand, combinations of malathion with peanut oil demonstrated lower hatchability $\%$ than that combined with abamectin.

Table 5. Effect of abamectin and malathion at three mixture ratios with olive, peanut and linseed oils on hatchability $\%$ of $C$. maculatus eggs

\begin{tabular}{|c|c|c|c|c|c|c|}
\hline \multirow{3}{*}{$\begin{array}{l}\text { Concentration } \\
(\mathrm{ppm})\end{array}$} & \multicolumn{6}{|c|}{ Hatchability \% } \\
\hline & \multicolumn{2}{|c|}{ Olive oil } & \multicolumn{2}{|c|}{ Peanut oil } & \multicolumn{2}{|c|}{ Linseed oil } \\
\hline & 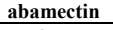 & & & & & \\
\hline \multicolumn{7}{|c|}{ oil : insecticide 5:95 } \\
\hline 10 & $77.6 \mathrm{~b}$ & $9 \mathrm{a}$ & $9 \mathrm{a}$ & $95.3 \mathrm{ab}$ & $95.8 \mathrm{a}$ & $100 \mathrm{a}$ \\
\hline 50 & $77.2 \mathrm{~b}$ & $95.8 \mathrm{a}$ & $97.7 \mathrm{a}$ & $93.2 \mathrm{ab}$ & $90.3 \mathrm{~b}$ & $92.5 \mathrm{ab}$ \\
\hline & $62.1 \mathrm{~cd}$ & $\mathrm{a}$ & 4 a & $91.3 \mathrm{ab}$ & $88.82 \mathrm{~b}$ & $91.7 \mathrm{ab}$ \\
\hline & $52.1 \mathrm{de}$ & $90.1 \mathrm{a}$ & $97.1 \mathrm{a}$ & $88.8 \mathrm{abc}$ & $83.6 \mathrm{c}$ & $89.1 \mathrm{abc}$ \\
\hline 1000 & $32.6 \mathrm{f}$ & 74. & $81.5 \mathrm{ab}$ & 75.4 cde & $62.3 \mathrm{f}$ & $80.8 \mathrm{bcd}$ \\
\hline \multicolumn{7}{|c|}{ oil : insecticide 10:90 } \\
\hline 10 & $76.4 \mathrm{~b}$ & $95.6 \mathrm{a}$ & $98.2 \mathrm{a}$ & $94.1 \mathrm{ab}$ & $90.8 \mathrm{~b}$ & 92.9 \\
\hline 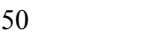 & $74 \mathrm{~b}$ & & $97.4 \mathrm{a}$ & $91.3 \mathrm{ab}$ & $89.8 \mathrm{~b}$ & $91.9 \mathrm{ab}$ \\
\hline & 57.4 cde & $92.9 \mathrm{a}$ & $97.4 \mathrm{a}$ & 85.4 abcd & $84.6 \mathrm{c}$ & 89.9 abc \\
\hline & $50.6 \mathrm{de}$ & $89.5 \mathrm{a}$ & $97.6 \mathrm{a}$ & 83. 6 abcd & $77.4 \mathrm{~d}$ & $80.8 \mathrm{bcd}$ \\
\hline 1000 & $30.4 \mathrm{f}$ & 67 & $81.5 \mathrm{ab}$ & $71.3 \mathrm{de}$ & $41.6 \mathrm{i}$ & 75.2 cde \\
\hline \multicolumn{7}{|c|}{ oil : insecticide 15:85 } \\
\hline$\overline{10}$ & $73.1 \mathrm{~b}$ & $94.1 \mathrm{a}$ & $97.6 \mathrm{a}$ & $92.8 \mathrm{ab}$ & $66.62 \mathrm{e}$ & 76.8 bcde \\
\hline-0 & $63.6 \mathrm{c}$ & & $95.1 \mathrm{a}$ & $87.5 \mathrm{abc}$ & $57.8 \mathrm{~g}$ & $67.1 \mathrm{de}$ \\
\hline 100 & $50.6 \mathrm{de}$ & $90.2 \mathrm{a}$ & $92.4 \mathrm{ab}$ & $82.7 \mathrm{abcd}$ & $46.2 \mathrm{~h}$ & $64.0 \mathrm{e}$ \\
\hline & $47.5 \mathrm{e}$ & $71.7 \mathrm{~b}$ & $85.4 \mathrm{ab}$ & $81.6 \mathrm{bcd}$ & $40.3 \mathrm{i}$ & 63.9 e \\
\hline 1000 & $30.4 \mathrm{f}$ & $40.4 \mathrm{c}$ & $75.8 \mathrm{~b}$ & $65.2 \mathrm{e}$ & $35.4 \mathrm{j}$ & $63.4 \mathrm{e}$ \\
\hline & $99.0 \mathrm{a}$ & $99.0 \mathrm{a}$ & $99.0 \mathrm{a}$ & $99.0 \mathrm{a}$ & $99.0 \mathrm{a}$ & $99.0 \mathrm{a}$ \\
\hline $\operatorname{LSD}(0.05)$ & 8.5 & 8.9 & 12.3 & 9.5 & 3.23 & 10.2 \\
\hline
\end{tabular}

Means followed by the same letters in a column insignificantly differences at $0.05 \%$ level.

These results confirmed by (Mohamed et al., 2009) who found that hatchability of C. maculatus were $69.73,44.81 \%$ at $0.5,2.5 \mathrm{ppm}$ of Avermectin, compared with $90.05 \%$ at check.

Regarding to the effect of the oil and insecticide mixtures on the numbers of emerged adults of cowpea weevil, the statistical analysis of the data in Table (6) indicated that the numbers of emerged adults were significantly differences than untreated control and all other treatments.
The results showed that the combinations of abamectin with olive oil and peanut oil was more effective in decreased the number of emerged adult compared with its combinations with malathion and malathion with linseed oil was more effective than abamectin .The abamectin combined with olive oils was the most effective in comparison with other mixtures.

It could be observed that the mixtures of the mixtures of 5:95, 10: 90 and 15:85 of olive oil and abamectin especially at 100, 500, $1000 \mathrm{ppm},(10: 90)$ and $(15: 85)$ of abamectin and linseed at concentration of 1000 ppm, at mixing ratios of (10:90) and (15:85) for linseed oil and malathion at 500 and $1000 \mathrm{ppm}$ gave complete protection of cowpea weevil resulting $100 \%$ reduction in adult emergency.

Table 6. Effect of abamectin and malathion at three mixture ratios with olive, peanut and linseed oils on emerged adults of $C$. maculatus

\begin{tabular}{|c|c|c|c|c|c|c|}
\hline \multirow[b]{2}{*}{$\begin{array}{l}\text { Concentration } \\
(\mathrm{ppm})\end{array}$} & \multicolumn{6}{|c|}{ Mean no. of emerged adults (Reduction \%) } \\
\hline & \multirow{2}{*}{$\begin{array}{r}\begin{array}{r}\text { Oli } \\
\text { abamecti }\end{array} \\
\text { de } 5: 95\end{array}$} & $\begin{array}{l}\text { e oil } \\
\text { malathion }\end{array}$ & \multicolumn{2}{|c|}{$\begin{array}{l}\text { Peanut oil } \\
\text { amectin malathion }\end{array}$} & \multicolumn{2}{|c|}{$\begin{array}{c}\text { Linseed oil } \\
\text { abamectin } \quad \text { Malathion }\end{array}$} \\
\hline \multicolumn{6}{|c|}{ oil : insecticide 5:95 } & \\
\hline 10 & $\begin{array}{l}10.7 \mathrm{~b} \\
(95.3)\end{array}$ & $\begin{array}{l}86.7 \mathrm{~b} \\
(61.5)\end{array}$ & $\begin{array}{c}33.3 \mathrm{bc} \\
(85.2)\end{array}$ & $\begin{array}{l}81.3 \mathrm{~b} \\
(63.9)\end{array}$ & $\begin{array}{l}38.7 \mathrm{~b} \\
(82.8)\end{array}$ & $\begin{array}{l}33.3 \mathrm{~b} \\
(85.2)\end{array}$ \\
\hline 50 & $\begin{array}{c}2 \mathrm{~b} \\
(99.1)\end{array}$ & $\begin{array}{l}34.3 \mathrm{~d} \\
(84.8)\end{array}$ & $\begin{array}{c}17.3 \mathrm{de} \\
(92.3)\end{array}$ & $\begin{array}{l}43.7 \mathrm{~d} \\
(80.6)\end{array}$ & $\begin{array}{c}16 \mathrm{c} \\
(92.9)\end{array}$ & $\begin{array}{l}22.7 \mathrm{c} \\
(89.9)\end{array}$ \\
\hline 100 & $\begin{array}{l}0.7 \mathrm{~b} \\
(99.7)\end{array}$ & $\begin{array}{l}12.7 \mathrm{e} \\
(94.4)\end{array}$ & $\begin{array}{l}15 \text { def } \\
(93.3)\end{array}$ & $\begin{array}{l}3 \mathrm{e} \\
3)\end{array}$ & $\begin{array}{l}7.3 \mathrm{~cd} \\
(96.8)\end{array}$ & $\begin{array}{c}5.7 \mathrm{~d} \\
(97.5)\end{array}$ \\
\hline 500 & $\begin{array}{l}0 \mathrm{~b} \\
(100)\end{array}$ & $\begin{array}{c}9 \mathrm{e} \\
(96.0)\end{array}$ & $\begin{array}{l}9 \mathrm{ef} \\
(96.0)\end{array}$ & $\begin{array}{l}14.7 \mathrm{f} \\
(93.5)\end{array}$ & $\begin{array}{c}5 \mathrm{~cd} \\
(97.8)\end{array}$ & $\begin{array}{c}2.7 \mathrm{~d} \\
(98.8)\end{array}$ \\
\hline 1000 & $\begin{array}{l}0 \mathrm{~b} \\
(100)\end{array}$ & $\begin{array}{c}6 \mathrm{e} \\
(97.3)\end{array}$ & $\begin{array}{l}2.3 \mathrm{e} \\
(98.9)\end{array}$ & $\begin{array}{c}9 \mathrm{f} \\
(96.0)\end{array}$ & $\begin{array}{l}4.7 \mathrm{~cd} \\
(97.9)\end{array}$ & $\begin{array}{l}0.3 \mathrm{~d} \\
(99.9)\end{array}$ \\
\hline \multicolumn{7}{|c|}{ oil : insecticide 10:90 } \\
\hline 10 & $\begin{array}{c}0.7 \mathrm{~b} \\
(99.7)\end{array}$ & $\begin{array}{l}86.3 \mathrm{~b} \\
(61.7)\end{array}$ & $\begin{array}{l}26.3 \mathrm{~cd} \\
(88.3)\end{array}$ & $\begin{array}{l}66.3 \mathrm{c} \\
(70.6)\end{array}$ & $\begin{array}{c}7 \mathrm{~cd} \\
(96.9)\end{array}$ & $\begin{array}{c}4 \mathrm{~d} \\
(98.2)\end{array}$ \\
\hline 50 & $\begin{array}{c}0.7 \mathrm{~b} \\
(99.7)\end{array}$ & $\begin{array}{l}34.3 \mathrm{~d} \\
(84.8)\end{array}$ & $\begin{array}{l}17 \mathrm{de} \\
(92.4)\end{array}$ & $\begin{array}{c}36 \mathrm{~d} \\
(84.0)\end{array}$ & $\begin{array}{l}4.7 \mathrm{~cd} \\
(97.9)\end{array}$ & $\begin{array}{c}1 \mathrm{~d} \\
(99.5)\end{array}$ \\
\hline 100 & $\begin{array}{l}0 \mathrm{~b} \\
(100)\end{array}$ & $\begin{array}{l}11 . \\
(94\end{array}$ & $\begin{array}{l}11 \text { ef } \\
(95.1)\end{array}$ & $\begin{array}{l}9.7 \mathrm{f} \\
(95.7)\end{array}$ & $\begin{array}{l}2.3 \mathrm{~cd} \\
(98.9)\end{array}$ & $\begin{array}{l}0.3 \mathrm{~d} \\
(99.9)\end{array}$ \\
\hline 500 & $\begin{array}{l}0 \mathrm{~b} \\
(100)\end{array}$ & $\begin{array}{c}9 \mathrm{e} \\
(96.0)\end{array}$ & $\begin{array}{l}5 \text { ef } \\
(97.8)\end{array}$ & $\begin{array}{l}6.7 \mathrm{f} \\
(97.0)\end{array}$ & $\begin{array}{c}0.7 \mathrm{~d} \\
(99.7)\end{array}$ & $\begin{array}{l}0 \mathrm{~d} \\
(100)\end{array}$ \\
\hline 1000 & $\begin{array}{c}0 \mathrm{c} \\
(100)\end{array}$ & $\begin{array}{l}4.7 \mathrm{e} \\
(97.7) \\
\end{array}$ & $\begin{array}{r}1.3 \mathrm{f} \\
(99.4) \\
\end{array}$ & $\begin{array}{r}5.6 \mathrm{f} \\
(97.5) \\
\end{array}$ & $\begin{array}{c}0 \mathrm{~d} \\
(100)\end{array}$ & $\begin{array}{c}0 \mathrm{~d} \\
(100)\end{array}$ \\
\hline \multicolumn{7}{|c|}{ oil : insecticide 15:85 } \\
\hline 10 & $\begin{array}{l}0.7 \mathrm{~b} \\
(99.7)\end{array}$ & $\begin{array}{l}56.7 \mathrm{c} \\
(78.8)\end{array}$ & $\begin{array}{l}38.5 \mathrm{~b} \\
(82.9)\end{array}$ & $\begin{array}{l}38.7 \mathrm{~d} \\
(82.8)\end{array}$ & $\begin{array}{l}3.3 \mathrm{~cd} \\
(98.5)\end{array}$ & $\begin{array}{c}1 \mathrm{~d} \\
(99.5)\end{array}$ \\
\hline 50 & $\begin{array}{l}0.7 \mathrm{~b} \\
(99.7)\end{array}$ & $\begin{array}{l}15.3 \mathrm{e} \\
(93.2)\end{array}$ & $\begin{array}{l}13 \mathrm{ef} \\
(94.2)\end{array}$ & $\begin{array}{l}15.3 \mathrm{ef} \\
(93.2)\end{array}$ & $\begin{array}{l}2.7 \mathrm{~cd} \\
(98.8)\end{array}$ & $\begin{array}{l}0.3 \mathrm{~d} \\
(99.9)\end{array}$ \\
\hline 100 & $\begin{array}{c}0 \mathrm{~b} \\
(100)\end{array}$ & $\begin{array}{c}12 \mathrm{e} \\
(94.7)\end{array}$ & $\begin{array}{l}6.7 \text { ef } \\
(97.0)\end{array}$ & $\begin{array}{c}9.3 \mathrm{f} \\
(95.9)\end{array}$ & $\begin{array}{l}1.7 \mathrm{~cd} \\
(99.2)\end{array}$ & $\begin{array}{l}0.3 \mathrm{~d} \\
(99.9)\end{array}$ \\
\hline 500 & $\begin{array}{l}0 \mathrm{~b} \\
(100)\end{array}$ & $\begin{array}{c}8 \mathrm{e} \\
(96.4)\end{array}$ & $\begin{array}{l}3.7 \text { ef } \\
(98.4)\end{array}$ & $\begin{array}{c}5.3 \mathrm{f} \\
(97.6)\end{array}$ & $\begin{array}{l}1.3 \mathrm{~cd} \\
(99.4)\end{array}$ & $\begin{array}{c}0 \mathrm{~d} \\
(100)\end{array}$ \\
\hline 1000 & $\begin{array}{c}0 \mathrm{~b} \\
(100)\end{array}$ & $\begin{array}{c}2.3 \mathrm{e} \\
(98.9)\end{array}$ & $\begin{array}{c}1 \mathrm{f} \\
(99.5)\end{array}$ & $\begin{array}{c}2.3 \mathrm{f} \\
(98.9)\end{array}$ & $\begin{array}{c}0 \mathrm{~d} \\
(100)\end{array}$ & $\begin{array}{c}0 \mathrm{~d} \\
(100)\end{array}$ \\
\hline 111 & $225.3 \mathrm{a}$ & $225.3 \mathrm{a}$ & $225.3 \mathrm{a}$ & $225.3 \mathrm{a}$ & $225.3 \mathrm{a}$ & $225.3 \mathrm{a}$ \\
\hline $\operatorname{LSD}(0.05)$ & 8.5 & 9.8 & 9.3 & 9.6 & 8.7 & 8.6 \\
\hline
\end{tabular}

Means followed by the same letters in a column insignificantly differences at $0.05 \%$ level.

Sridevi and Dhingra (1996, 2000) evaluated the efficacy of deltamethrim and in mixture with linseed, ,neem and citronella oils as four ratios (1:1, 1:2, 1:4, 1:8) against susceptible and resistant strains of $T$. castaneum adults by direct spray and film residue methods and found that all vegetable oils had additive action.

As for seed weight loss percentages caused by $C$. maculatus infestation, the statistical analysis of the results in Table (7) indicated that the values of loss seed weight were significantly differences compared with untreated control and all other treatments. 
The highest loss percentage in seed weight was recorded at the treatment $10 \mathrm{ppm}$ of peanut: malathion at the mixture ratio of 5:95 resulting $22 \%$ comparing with $56 \%$ at untreated control with significant difference. It was observed that the seed weight loss was decreased as the concentration of combinations increased, indicating a negative relation between the concentrations and the weight loss percentage and more seed protection.

Table 7. Effect of abamectin and malathion at three mixture ratios with olive, peanut and linseed oils on weight loss \% of cowpea seeds infested by $C$. maculatus

\begin{tabular}{|c|c|c|c|c|c|c|}
\hline \multirow{2}{*}{$\begin{array}{l}\text { Concentration } \\
(\mathrm{ppm})\end{array}$} & \multicolumn{6}{|c|}{ Weight loss (\%) } \\
\hline & \multirow{2}{*}{\multicolumn{2}{|c|}{$\begin{array}{c}\begin{array}{c}\text { Olive oil } \\
\text { abamectin malathion }\end{array} \\
\text { e } 5: 95\end{array}$}} & \multicolumn{2}{|c|}{$\begin{array}{c}\text { Peanut oil } \\
\text { abamectin malathion }\end{array}$} & \multicolumn{2}{|c|}{$\begin{array}{c}\text { Linseed oil } \\
\text { abamectin Malathior }\end{array}$} \\
\hline \multicolumn{5}{|c|}{ oil : insecticide 5:95 } & & \\
\hline 10 & $5 \mathrm{~b}$ & $19.7 \mathrm{~b}$ & $8.5 \mathrm{~b}$ & $22 \mathrm{~b}$ & $15.8 \mathrm{~b}$ & $12 \mathrm{~b}$ \\
\hline 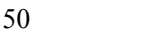 & $3 \mathrm{bc}$ & $10.7 \mathrm{c}$ & $5.6 \mathrm{bc}$ & $17 \mathrm{c}$ & $13.5 \mathrm{bc}$ & $10 \mathrm{bc}$ \\
\hline & $1.5 \mathrm{bc}$ & & $4 \mathrm{bcd}$ & $13.3 \mathrm{~cd}$ & $13.2 \mathrm{bc}$ & $4.5 \mathrm{de}$ \\
\hline & $1.3 \mathrm{bc}$ & $4.3 \mathrm{~d}$ & $1 \mathrm{~d}$ & $3.3 \mathrm{f}$ & 11.4 bcde & $2.6 \mathrm{de}$ \\
\hline 1000 & $0.83 \mathrm{bc}$ & $\mathrm{d}$ & $0 \mathrm{~d}$ & $0.3 \mathrm{f}$ & $8.4 \mathrm{c}$ & $0.8 \mathrm{e}$ \\
\hline \multicolumn{7}{|c|}{ oil : insecticide 10:90 } \\
\hline 10 & $3.8 \mathrm{bc}$ & $5 \mathrm{~b}$ & $6.2 \mathrm{bc}$ & $15.7 \mathrm{c}$ & $13.5 \mathrm{bc}$ & $12 \mathrm{~b}$ \\
\hline & $2.5 \mathrm{bc}$ & $3 \mathrm{c}$ & $4.3 \mathrm{bcd}$ & $12.3 \mathrm{~cd}$ & 10.1 bcdef & $5 \mathrm{de}$ \\
\hline & $1.5 \mathrm{bc}$ & $5.3 \mathrm{~cd}$ & $3.9 \mathrm{bcd}$ & $9.7 \mathrm{de}$ & 7.07 defg & $3.7 \mathrm{de}$ \\
\hline & $0.7 \mathrm{bc}$ & $4 \mathrm{~d}$ & $0 \mathrm{~d}$ & $0.3 \mathrm{f}$ & $6.6 \mathrm{efg}$ & $1.3 \mathrm{e}$ \\
\hline 1000 & $0.7 \mathrm{bc}$ & d & $0 \mathrm{~d}$ & $0 \mathrm{f}$ & $2.4 \mathrm{gh}$ & $0.3 \mathrm{e}$ \\
\hline \multicolumn{7}{|c|}{ oil : insecticide $15: 85$} \\
\hline 10 & $2.7 \mathrm{bc}$ & $10.7 \mathrm{c}$ & $6 \mathrm{bc}$ & 6 ef & $12.7 \mathrm{bcd}$ & $7 \mathrm{~cd}$ \\
\hline & $2.5 \mathrm{bc}$ & & $1.7 \mathrm{~cd}$ & $3.5 \mathrm{f}$ & $5 \mathrm{fgh}$ & $3.7 \mathrm{de}$ \\
\hline & $1.3 \mathrm{bc}$ & $4.5 \mathrm{~d}$ & $0.7 \mathrm{~d}$ & $3.9 \mathrm{f}$ & $4.7 \mathrm{fgh}$ & $3.3 \mathrm{de}$ \\
\hline & $0 \mathrm{c}$ & $3 \mathrm{~d}$ & $0 \mathrm{~d}$ & $0 \mathrm{f}$ & $1.3 \mathrm{gh}$ & $1 \mathrm{e}$ \\
\hline & $0 \mathrm{c}$ & $0.4 \mathrm{~d}$ & $0 \mathrm{~d}$ & $0 \mathrm{f}$ & $0.7 \mathrm{~h}$ & $0 \mathrm{e}$ \\
\hline & $56.0 \mathrm{a}$ & $56.0 \mathrm{a}$ & $56.0 \mathrm{a}$ & $56.0 \mathrm{a}$ & $56.0 \mathrm{a}$ & $56.0 \mathrm{a}$ \\
\hline $\operatorname{LSD}(0.05)$ & 2.7 & 3.9 & 2.99 & 4.5 & 4.01 & 3.2 \\
\hline
\end{tabular}

Means followed by the same letters in a column insignificantly differences at $0.05 \%$ level.

Combinations of abamectin with olive oil and peanut oil demonstrated lower weight loss \% than malathion, on the other side combinations of malathion with linseed oil was more effective in decreasing weight loss \% than abamectin.

Complete protection of treated seeds form weevil infestation was achieved with abamectin/olive oil (15:85) at the concentrations of 500 and $1000 \mathrm{ppm}$, and abamectin /peanut oil (5:95) at $1000 \mathrm{ppm}$, in addition to the treatments of abamectin /peanut oil (10:90 \& 15:85) at the concentrations of 500 and $1000 \mathrm{ppm}$, malathion/peanut oil (10:90) at $1000 \mathrm{ppm}$ and (15:85) at 500 and $1000 \mathrm{ppm}$ and malathion/linseed oil (15:85) at $1000 \mathrm{ppm}$, resulting $0 \%$ loss in seed weight comparing with $56 \%$ at control.

Finally, it could be concluded that the use of botanical oils mixed with abamectin and malathion gave complete protection to cowpea seeds from the infestation with Cowpea seed weevil (Callosobruchus maculatus), in addition minimized insecticide usage and reduce health hazards to applicators and one of the main advantages is that plant oils are more readily biodegradable; they may be simply and economically produced by farmers as crude or partly refined extracts. Though, application of plant oils to common bean seeds for storage is an inexpensive and effective technique leading to acceptance of this technology by farmers. Also, it could be a components of integrated storage pest management. The neem and linseed oils fully inhibit survival of immature stages of Callosobruchus chinensis as well as emerged adults (Ahmed et al., 1999). Also, Mohammed et al. (2009) indicated that the weight loss in legume seeds produced by C. maculatus was small in avermectin treatments resulting $10.28 \%$ compared to the leufenuron treatments $(20.38 \%)$.

\section{REFERENCES}

Abbott, W.S. (1925). A method for computing the effectiveness of an insecticide. ( $J$. Econ. Entomol., 18 : 265-267).

Abdel-razik, M.A.A; M.H. Rashwan and L.T.H.Zidan (2013).Insecticidal activity of pyridalyl, spinosad alone and combined with vegetable oils on growth development and reproductive performance of $C$. maculatus. (Nature and Science. 11(4). 118-127).

Adebowale, K.O. and C.O. Adedire (2006). Chemical composition and insecticidal properties of the underutilized Jartropha curcas oil. (African J. Biotechnol. 5:901-906).

Abo El-ghar, G; A. E. El-sheikh; F.M. El-sayed; H.M.Elmaghraby; and H.M.El-zun (2003). Persistence and residual activity of an organophosphate, pirimiphos-methyl and three IGRs, hexaflumuron, teflubenzuron and pyriproxyfen against the cowpea weevil, Callosobruchus maculatus (F.) (Coleoptera: Bruchidae). (Pest Mang.Sci: 60:95-102).

Ahmed, H. and B.G. Gardiner (1967), Effect of mineral oil solvent on toxicity and speed of action of Malathion. (Nature. 241:1338-1339).

Ahmed, K.S., T. Itino and T. Ichikawa (1999): Effects of plant oils on oviposition preference and larval survivorship of Callosobruchus chinensis (Coleoptera: Bruchidae) on azuki bean. (Applied Entomol. Zool. 34:547-550).

COSTAT version 6.400 copyright (C) 1998-2008: Cohort Software. 798 Lighthouse Ave. PMB 320, Monterey, CA, 93940, USA.

Don-Perdo, K.N. (1989 a). Mechanisms of action of some vegetable oils against Sitophilus zeamais (Motsch) (Coleoptera:Curculionidae) on wheat . (J. Stored Prod. Res., 25:217-223).

Don-Pedro,K.N.(1989b). Mode of action of fixed oils against eggs Callosobruchus maculatus (F.). (Pest.Sci. 26:107-115).

Finney, D.J. (1971): Probit analysis (3 rd Ed., Cambridge, Univ. Press, London).

Keita, S.M.; C. Vincent; J.P. Schnit; S. Ramaswamy and A. ramaswamy. (2000). Effect of various essential oils on Callosobruchus maculates (F.) (Coleoptera: Bruchidae). (J. Stored Prod. Res.36, 355-364).

Khare, B.P. and R.K. Johari (1984). Influence of phenotypic characters of chickpea (Cicer arietinum) cultivars on their susceptibility toCalosobruchus chinensis (L.). (Legume Res., 7:54-56).

Mohamed, H.A; O.E. El-Sebai and and S.F. Hafez (2009). Effect of lufenuron and methylamine avermectin on growth, development and reproductive performance of Callosobruchus maculatus) F.). (Coleoptera: Bruchidae). (Bull. Ent. Soc. Econ. Ser. 35(75-90). 
Mulatu. B. and T. Gebremedhin (2000). Oviposition deterrent and toxic effects of various botanicals on the Adzuki bean beetle Callosobruchus chinensis L. (Insect Sci. Appl., 20:33-38).

Ouedraogo, A.P.; S. Sou; A. Sanon; J.Monge; J. Huignard and P.F. Credl (1996). Influence of temperature and humidity on population of Calosobruchus maculatus (Coleoptera: Bruchidae) and its parasitoid Dinarmus basalis (Pteromalidae) in two zones of Burkina Faso. (Bull. Entomol. Res., 86:695-702).

Onolemhemhem, O.P. (2001). Evaluation of rubber seed oil for the control of rice weevil, Sitophilus oryzae L. (J. Agric. For Fis., 2: 23- 26).

Pacheco, I .A. M. R. Sartori and R. W. D. Taylor. (1990). Levantamento de resistencia de insetospragas de graos armazenados a fos.na, no Estado de sao Paulo. (Coletanea do institudo de Technologia de Alimentos, 20: 144-154).

Sartori, M.R.; I.A. Pacheco; M. Laderosa; and R.W.D. Taylor (1990).Ocorrencia e especi. ciadade de resistencia ao insecticide malathion em insetospragas de graos armazenados, no Estado de Sao Paulo. (Coletanea de Institudo de Technologia de Alimentos. 20: 194- 209).
Sridevi, D.; and S. Dhingra (1996). Evaluation of some non-toxic vegetable oils as synergists for different synthetic pyrethroids in mixed formulations against Tribolium castaneum (Herbst). (J. Entomol. Res. New Delhi, 20: 335- 343).

Sridevi, D. and S. Dhingra (2000). Evaluation of mixtures of non-toxic vegetable oils and deltamethrim against susceptible and resistant strains of Tribolium castaneum ( Herbst).( J .E ntomol. Res., New Delhi 24: 375-382).

Sun, Y.P. and E.R. Johanson (1960): Analysis of joint action of insecticides against house flies. J. Econ. Entomology. 53 (5): 887-892.

Swella, G.B.; and Mushobozy, D.M.K.(2007) . Evaluation of the efficacy of protectants against cowpea bruchids Calosobruchus maculatus F. on cowpea seeds (Vigna unguiculata (L.) Walp.) Plant protect Sci., 43: 68-72.

Tapondjou,L.A. ;Alder,A.C.; BoudA,H. and Fontem,D.A. (2002). Efficacy of powder and essential oil from Chemopodium ambrosiodes leaves as post-harvest grain protectants against six stored product beetles. (J. Stored Products Res., 38: 395- 402).

Tembo, E. and R.F.A. Murfitt (1995). Effect of combining vegetable oil with pirimiphos-methyl for protection of stored wheat against Sitophilus granarius (L.). (J. Stored Prod. Res., 31: 77-81).

\section{التاثير ات التوكسيكولوجية و البيولوجية لمبيدى الابامساكتين والمـالاثيون وثلاثتة زيوت نباتية منفردة وفى مخـاليط على خنفساء اللوبيا منال عبد الرؤوف عبد المجيد عبد الرازق الريا قسم مبيذات الافات كلنية الزراعة - جامعة المنوفية}

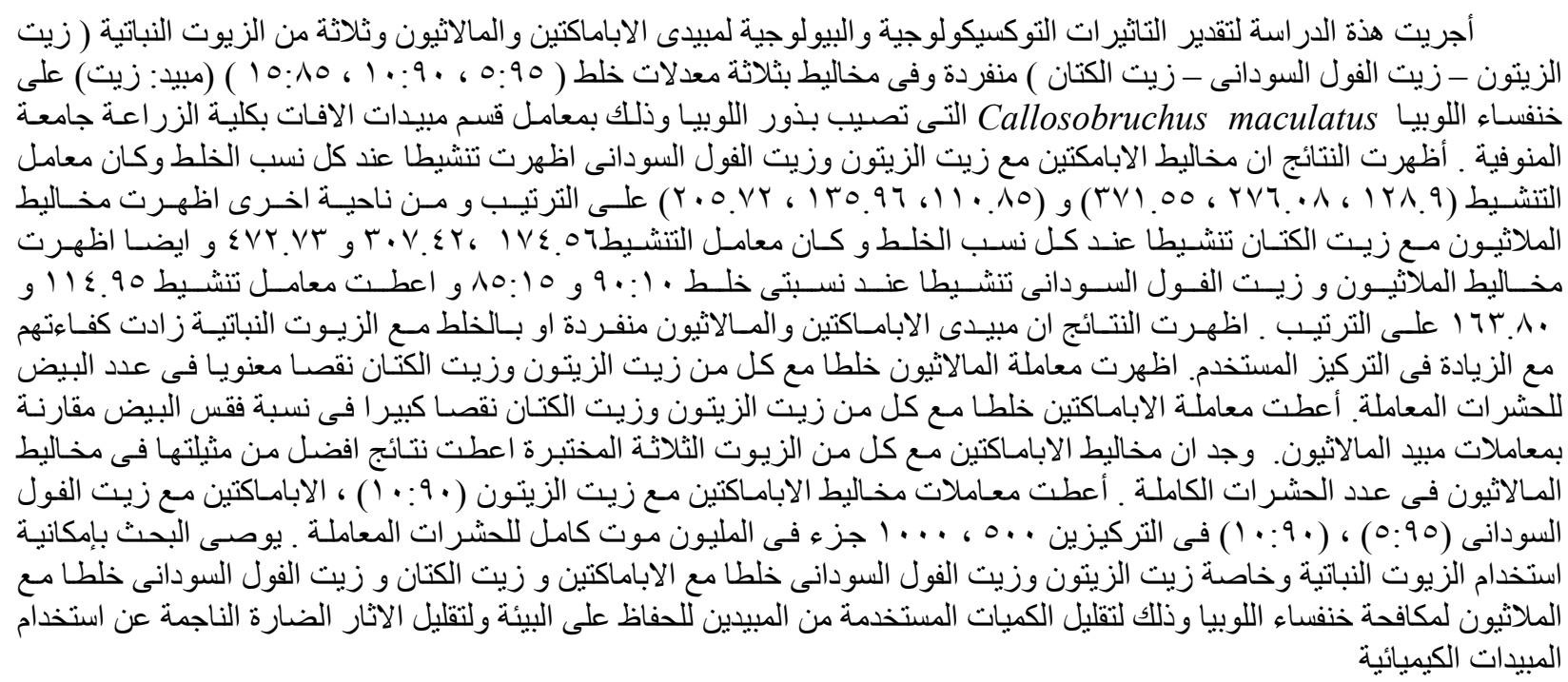

